\section{Host status of progenies of yellow passion fruit to Meloidogyne incognita race 2}

\section{Roxana Stefane Mendes Nascimento ${ }^{1}$, Everaldo Antônio Lo- pes $^{1^{*}}$, Carlos Eduardo Magalhães dos Santos ${ }^{2}$, Viviane Manuela Bernardes Silva Magalhães ${ }^{1}$ and José Avelino Cardoso ${ }^{3}$}

\begin{abstract}
The host status of eighteen progenies (CRP 01-12 to CRP 16-12, CRP 19-12 and CRP 20-12) and two cultivars (FB 200 Yellow Master and FB 300 Araguari) of yellow passion fruit to Meloidogyne incognita race 2 was evaluated in a greenhouse experiment. The height and the biomass of the plants, besides the numbers of galls, eggs and second-stage juveniles in roots and soil were assessed after 70 days of cultivation of the genotypes and tomato (control) in plastic pots with $2 \mathrm{~kg}$ of soil infested with 5,000 eggs of the nematode. The reproduction factor of the pathogen ( $R F=$ Final population/Initial population) was calculated for classifying the genotypes as immune $(R F=0)$, resistant ( $R F$ $<1)$ or susceptible $(R F \geq 1)$. The cultivar FB 200 is resistant to $M$. incognita race 2 and can be cultivated in areas infested with this nematode.
\end{abstract}

Key words: Root-knot nematode, Passiflora edulis, resistance.

\section{INTRODUCTION}

The yellow passion fruit (Passiflora edulis Sims) is grown in almost all states of Brazil, especially on small farms. Due to the constant demand for fruit juice industry processing, passion fruit culture is an important source of income for many families in the country. However, the Brazilian passion fruit productivity is still low (Reis et al. 2012), and the occurrence of diseases is one of the main drivers of this scenario. Early plant death, defoliation, delay in fruit ripening and reduced pulp yield are some of the symptoms caused by pathogens of passion fruit that reduce the production and fruit quality.

The passion fruit grows in the same area of cultivation for several years. Thus, soil-borne pathogens that attack the root system of the plant, such as root-knot nematodes (Meloidogyne spp. Goeldi), may be responsible for reducing the longevity of the same orchard or non-viability of the crop in the infested area (Dias-Arieira et al. 2010). Worldwide, the species Meloidogyne incognita (Kofoid and White) Chitwood is one of the most widespread and aggressive, with the largest host range, in which the passion fruit is included (Moens et al. 2009, Fisher et al. 2010, Rocha et al. 2013).

The use of resistant varieties is the most suitable method for managing nematodes (Ferraz et al. 2010). The selection of passion fruit genotypes resistant to polyphagous nematodes, such as $M$. incognita, as well as maintenance of the productive potential of the plant in the presence of nematodes can generate an alternative growing option in infested areas and limited to planting host
Crop Breeding and Applied Biotechnology 16: 153-157, 2016 Brazilian Society of Plant Breeding. Printed in Brazil http://dx.doi.org/10.1590/1984$70332016 v 16 n 2$ n23

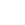


crops. However, few studies have been conducted in Brazil in order to select passion fruit genotypes resistant to only the root-knot nematode (Sharma et al. 2002, 2004, Garcia et al. 2008, El-Moor et al. 2009, Garcia et al. 2011, Rocha et al. 2013) an only Garcia et al. (2008) evaluated the reaction of two cultivars (Afruvec and Maguary) to race 2 of $M$. incognita. Thus, the aim of this study was to evaluate the reaction of 18 genotypes were selected from the Genetic Breeding Program of the Universidade Federal de Viçosa and two cultivars (FB 200 Yellow Master and FB 300 Araguari) of passion fruit to $M$. incognita race 2 .

\section{MATERIAL AND METHODS}

The 18 genotypes of passion fruit (CRP 01-12 to CRP 16-12, CRP 19-12 and CRP 20-12) were considered superior for productivity and fruit quality; they were recombined and selected in previous cycles of selection among and within families structured in half sib. The FB 200 Yellow Master and FB 300 Araguari cultivars were also included in the work because they are commonly grown in Brazil.

The inoculum of $M$. incognita race 2 was obtained from pure populations maintained in tomato (Solanum lycopersicum L. 'Santa Cruz') grown in 2-L plastic pots containing $2 \mathrm{~kg}$ of soil: autoclaved sand $\left(120^{\circ} \mathrm{C}\right.$ for $2 \mathrm{~h}$ ) mix (1:1, v/v) under greenhouse conditions.

Seedlings of passion fruit genotypes were also grown in plastic pots containing $2 \mathrm{~kg}$ of soil substrate:autoclaved sand. Inoculation with a suspension of $M$. incognita eggs occurred when the plants reached the 10 -leaf stage. Each plant was inoculated with a 2-mL suspension containing 5000 eggs of the nematode deposited into two holes in the soil near the plant stem ( $4 \mathrm{~cm}$ away from the stem and $5 \mathrm{~cm}$ deep). The pathogen eggs were extracted by the technique of Hussey and Barker (1973), modified by Boneti and Ferraz (1981). The plants were grown in a greenhouse for 70 days. During this period, the mean maximum and minimum temperatures were 35.5 and $18.5^{\circ} \mathrm{C}$, respectively.

The experiment was evaluated by measuring plant height, shoot biomass and fresh roots, and by counting the numbers of galls and nematode eggs in the roots and the second stage juveniles (J2) in the roots and soil. The assessment of the number of galls per plant was performed by direct counting with the naked eye and converting to the gall index (GI) proposed by Taylor and Sasser (1978), where: Note 0 = no gall rating; Note 1 = 1-2 galls; Note 2 = 3-10 galls; Note $3=$ $11-30$ galls; Note $4=31-100$ galls; and Note $5=$ more than 100 galls. The extractions of the eggs in the roots, J2 in the roots and soil were made following the methods proposed by Boneti and Ferraz (1981), Coolen and D'Herde (1972) and Jenkins (1964), respectively. Eggs and vermiform stages of nematodes were counted with the aid of a Peters chamber and observation under a stereoscopic microscope, at a magnification of 40 times.

The reproduction factor (RF) of the nematode was calculated using the ratio of the final population of the nematodes in roots and soil to the initial population (5000 eggs), introduced during inoculation. The genotypes of passion fruit were rated for resistance to nematodes by their $\mathrm{RF}$, where: $\mathrm{RF}=0$ is immune (I); $0<\mathrm{RF}<1$ is resistant $(\mathrm{R})$; and $\mathrm{RF} \geq 1$ is susceptible (S) (Oostenbrink 1966).

The experiment was conducted using a randomized complete block design with 21 treatments ( 20 genotypes of passion fruit + tomato) and four replications, with each plot represented by three plants kept in separate pots. Non-inoculated plants were maintained to compare the effects of the nematode on the growth of passion fruit genotypes, making a $20 \times 2$ factorial (genotypes $x$ with or without M. incognita). 'Santa Cruz' tomatoes were used as a susceptible control.

The data were submitted to normality (Shapiro-Wilk test) and homogeneity of experimental error tests (Levene test) and then were subjected to analysis of variance at the $5 \%$ probability by an $\mathrm{F}$ test, processed or not for $\log _{10}(\mathrm{x})$. The treatment means were compared by the Scott-Knott test at 5\% probability, with the exception of the GI, where Friedman's test at the $5 \%$ probability was used.

\section{RESULTS AND DISCUSSION}

There was no gall formation on any of the 20 genotypes (Table 1 ), equivalent to note 0 . On the other hand, hundreds of thousands of eggs and galls were observed in tomato roots (note 5), confirming that the viability of the inoculum and environmental conditions during the experiment allowed the nematodes to complete their life cycle. For the criterion proposed by Taylor and Sasser (1978), all genotypes and cultivars can be considered resistant, since the GI was equal to 
zero. However, the interaction between Meloidogyne and passion fruit does not necessarily result in galling, as reported by Garcia et al. (2008) and Rocha et al. (2013). In some cases, few galls can be formed, but the plant still behaves as a good nematode host (El-Moor et al. 2006). The nematodes can penetrate the roots and induce root transformation of cells by injection of esophageal secretions. In most pathosystems involving nematode galls, the hyperplasia and hypertrophy processes occur in infected roots (Castagnone-Sereno et al. 2013). The galling process results in hyperplasia, or cell division of root tissue altered by the action of nematode secretions. However, the establishment of the nematode in roots depends mainly on formation and maintenance of giant cells, which serve as nutrient reservoirs and results from hypertrophy processes (Castagnone-Sereno et al. 2013).

Thus, even in the absence of the typical symptoms of galls, Meloidogyne species can infect and replicate in host tissue as long as the giant cells are formed. It is possible to infer that such a situation occurred with half of the genotypes (CRP 03-12, CRP 04-12, CRP 05-12, CRP 07-12, CRP 09-12, CRP 10-12, CRP 12-12, CRP 14-12, CRP 15-12 and FB 300), considering that the numbers of nematodes in the roots of these plants ranged from 12,163 (CRP 04-12) to 31,391 (CRP 03-12), with population growth between 2.4 and 6.2 times the amount of initial inoculum (Table 1). Because the juveniles hatching efficiency cannot be absolute (Castagnone-Sereno et al. 2013), the population increase in this case could have been much higher. On the other hand, the number of nematodes in the roots was lower than the initial inoculum (FB 200), and in other genotypes numbers ranged up to 10,757 (CRP 06-12) juveniles or eggs, with no difference between them (Table 1).

In turn, based on the RF of the nematode, it was observed that all genotypes drastically reduced the final population of $M$. incognita in comparison to the susceptible tomato control (RF $0.5-6.3$ and 764.9, respectively) (Table 1). However, only the FB 200 can be considered resistant to $M$. incognita race 2 by allowing an RF smaller than 1 (Oostenbrink 1966). It is possible that this genotype limits processes vital to the establishment of the nematodes and the formation or maintenance of giant cells, and/or it is possible that inhibitory substances are produced in the roots (Pegard et al.

Table 1. Reaction of 20 genotypes of passion fruit (Passiflora edulis f. flavicarpa) and tomato (Solanum lycopersicum 'Santa Cruz') to Meloidogyne incognita race 2 at 70 days of cultivation in greenhouse

\begin{tabular}{|c|c|c|c|c|c|}
\hline Genotypes & $\mathbf{G l}^{1}$ & $\begin{array}{l}\text { Numbers of nematode in the roots (eggs + } \\
\text { stage juveniles) }{ }^{* 2}\end{array}$ & $\begin{array}{l}\text { Numbers of stage juveniles in } \\
\text { the soil }{ }^{* 2}\end{array}$ & $\mathrm{RF}^{* 2}$ & $\begin{array}{l}\text { Resistance } \\
\text { (RF) }\end{array}$ \\
\hline CRP 01-12 & $0 \mathrm{~b}$ & $5,333.8 c$ & $100.0 \mathrm{c}$ & $1.1 \mathrm{~b}$ & $S$ \\
\hline CRP 02-12 & $0 \mathrm{~b}$ & $10,083.8 \mathrm{c}$ & $185.0 \mathrm{c}$ & $2.1 \mathrm{~b}$ & S \\
\hline CRP 03-12 & $0 \mathrm{~b}$ & $31,391.4 \mathrm{~b}$ & $180.0 \mathrm{c}$ & $6.3 \mathrm{~b}$ & $S$ \\
\hline CRP 04-12 & $0 \mathrm{~b}$ & $12,163.6 \mathrm{~b}$ & $430.0 \mathrm{~b}$ & $2.5 \mathrm{~b}$ & $\mathrm{~S}$ \\
\hline CRP 05-12 & $0 \mathrm{~b}$ & $18,375.8 \mathrm{~b}$ & $176.2 \mathrm{c}$ & $3.7 \mathrm{~b}$ & S \\
\hline CRP 06-12 & $0 \mathrm{~b}$ & $10,757.3 \mathrm{c}$ & $522.5 \mathrm{~b}$ & $2.3 \mathrm{~b}$ & $S$ \\
\hline CRP 07-12 & $0 \mathrm{~b}$ & $15,137.1 \mathrm{~b}$ & $537.5 \mathrm{~b}$ & $3.1 \mathrm{~b}$ & $S$ \\
\hline CRP 08-12 & $0 \mathrm{~b}$ & $9,706.4 \mathrm{c}$ & $292.5 \mathrm{~b}$ & $2.0 \mathrm{~b}$ & $S$ \\
\hline CRP 09-12 & $0 \mathrm{~b}$ & $17,555.4 \mathrm{~b}$ & $242.5 \mathrm{~b}$ & $3.5 \mathrm{~b}$ & $S$ \\
\hline CRP $10-12$ & $0 \mathrm{~b}$ & $26,783.4 \mathrm{~b}$ & $122.5 \mathrm{c}$ & $5.4 \mathrm{~b}$ & $S$ \\
\hline CRP $11-12$ & $0 \mathrm{~b}$ & $7,575.1 \mathrm{c}$ & $122.5 \mathrm{c}$ & $1.5 \mathrm{~b}$ & $S$ \\
\hline CRP $12-12$ & $0 \mathrm{~b}$ & $14,970.2$ b & $192.5 \mathrm{c}$ & $3.0 \mathrm{~b}$ & $S$ \\
\hline CRP $13-12$ & $0 \mathrm{~b}$ & $8,091.7 \mathrm{c}$ & 192.5 c & $1.6 \mathrm{~b}$ & $S$ \\
\hline CRP 14-12 & $0 \mathrm{~b}$ & $22,005.6 \mathrm{~b}$ & $162.5 \mathrm{c}$ & $4.4 \mathrm{~b}$ & $S$ \\
\hline CRP 15-12 & $0 \mathrm{~b}$ & $12,580.7 \mathrm{~b}$ & $442.5 \mathrm{~b}$ & $2.6 \mathrm{~b}$ & $S$ \\
\hline CRP $16-12$ & $0 \mathrm{~b}$ & $5,015.8 \mathrm{c}$ & $222.5 \mathrm{~b}$ & $1.0 \mathrm{~b}$ & $S$ \\
\hline CRP 19-12 & $0 \mathrm{~b}$ & $7,623.3 \mathrm{c}$ & $160.0 \mathrm{c}$ & $1.5 \mathrm{~b}$ & $S$ \\
\hline CRP 20-12 & $0 \mathrm{~b}$ & $6,740.5 \mathrm{c}$ & $267.5 \mathrm{~b}$ & $1.4 \mathrm{~b}$ & $S$ \\
\hline FB 200 & $0 \mathrm{~b}$ & $2,089.1 \mathrm{c}$ & $300.0 \mathrm{~b}$ & $0.5 \mathrm{~b}$ & $\mathrm{R}$ \\
\hline FB 300 & $0 \mathrm{~b}$ & $15,748.5 b$ & $155.0 \mathrm{~b}$ & $3.1 \mathrm{~b}$ & $S$ \\
\hline Tomato & $5 a$ & $3,816,000.0 \mathrm{a}$ & $8,666.3 \mathrm{a}$ & $764.9 \mathrm{a}$ & $S$ \\
\hline CV (\%) & 6.7 & 13.40 & 35.63 & 47.87 & - \\
\hline
\end{tabular}

Average of four replications. Means followed by the same lower-case letter in the column do not differ by the Friedman (1) or Scott-Knott tests (2) at $5 \%$ probability. * Data

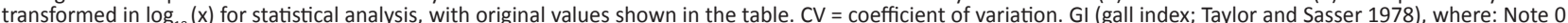
$=$ no gall; Note $1=1-2$ galls; Note $2=3-10$ galls; Note $3=11-30$ galls; Note $4=31-100$ galls; and Note $5=$ more than 100 galls. Reproduction factor (RF), where RF = 0 is immune (I); $0<R F<1$ is resistant (R); and RF $\geq 1$ is susceptible (S) (Oostenbrink 1966). 
Table 2. Vegetative development of 20 genotypes of passion fruit (Passiflora edulis f. flavicarpa) grown in a greenhouse in pots containing soil infested (SI) or not infested (SNI) with Meloidogyne incognita race 2

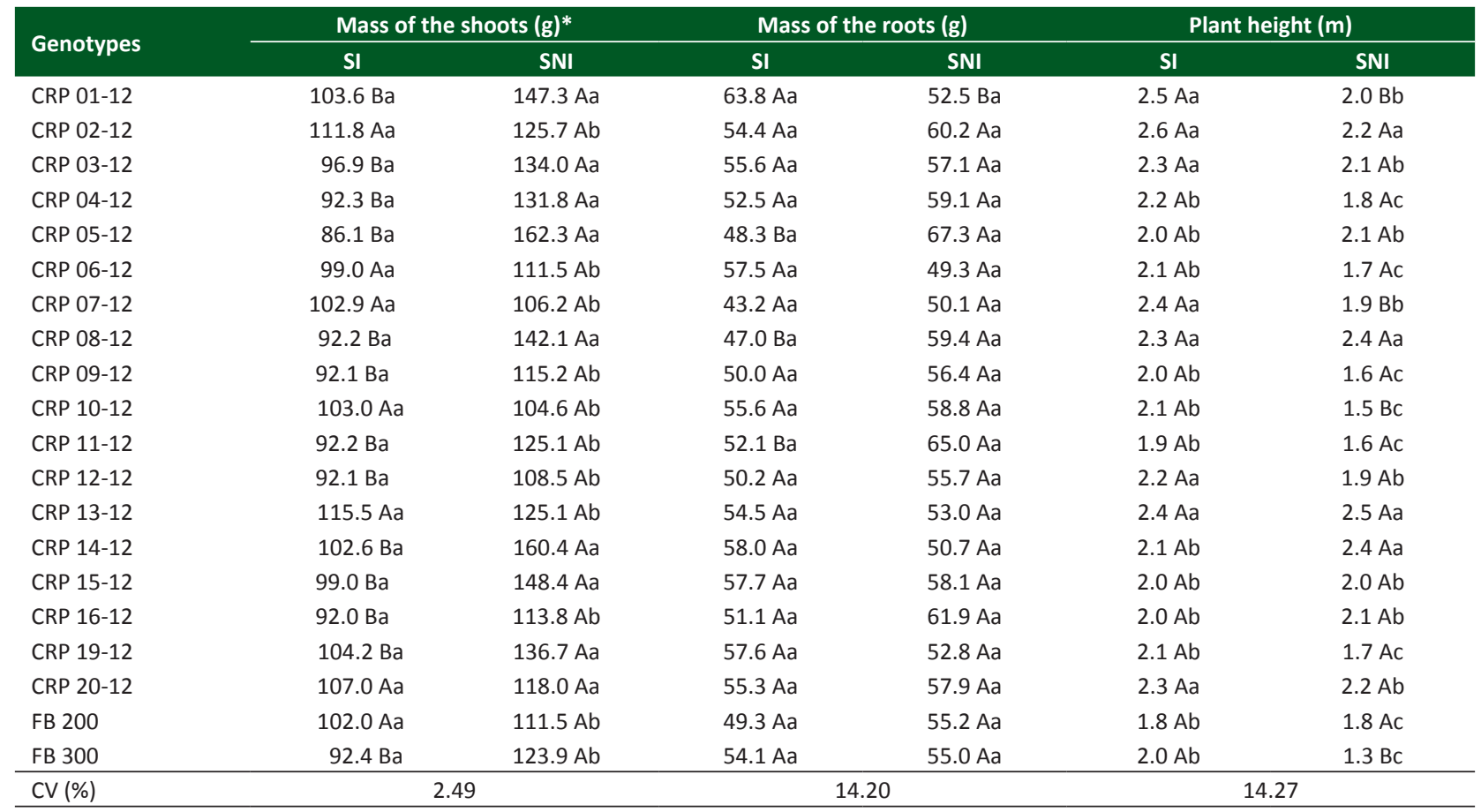

Average of four replications. Means followed by the same lower-case letter in the column and capital letter on the line do not differ by the Scott-Knott test at $5 \%$ probability. * Data transformed to $\log _{10}(\mathrm{x})$ for statistical analysis. Original values are shown in the table. CV = coefficient of variation.

2005, Proite et al. 2008). Histological and biochemical studies in the future could elucidate the events responsible for the resistance of the cultivar FB 200. The pathogen RF of progeny CRP 16-12 was approximately 1 (Table 1). Thus, while allowing the nematode to reproduce in its tissues, the growth rate of the population is low; this genotype may be considered in future breeding programs for resistance to $M$. incognita race 2.

The vegetative development of passion fruit varied depending on the interaction between genotypes and the presence of $M$. incognita race 2 in the soil (Table 2). The mass of the shoots (MSH) of the plants was reduced when the crop occurred in soil infested with the nematode compared to those of non-infested plots, with the exception of genotypes CRP 02-12, CRP 06-12, CRP 07-12, CRP 10-12, CRP 13-12, CRP 20-12 and FB 200, of which MSH values were similar in both conditions. In turn, plant height and the mass of the roots (MR) were not reduced due to nematode parasitism in most genotypes. Only progenies CRP 01-12, CRP 07-12, CRP 10-12 and cultivar FB 300 Araguari grew less in the presence of nematodes, and there were reductions in MR in genotypes CRP 05-12, CRP 08-12 and CRP 11-12 in infested soil (Table 2). In infested soil, there was no difference in MSH and MR among genotypes, while the heights of progenies CRP 01-12, CRP 02-12, CRP 03-12, CRP 07-12, CRP 08-12, CRP 12-12, CRP 13-12 and CRP 20-12 were higher than other materials (Table 2).

Changes in plant development in the presence of nematodes depend mainly on density and aggressiveness of the inoculum, the environmental conditions and the genotype involved (Fourie et al. 2010, Santos et al. 2012). In general, changes in the absorption and translocation of water and nutrients induced by parasitic nematode gall activity can delay the growth of the root, thereby contributing to a reduction in plant growth (Sharma et al. 2001). Due to the similarity of inoculum conditions and environment between treatments, the genetic variability among genotypes allowed different responses among the genotypes of passion fruit (Wilcken et al. 2005, El-Moor et al. 2009). While the parasitic nematode induces a reduction in the development of some genotypes of passion fruit (Sharma et al. 2001), others tolerate the presence of the pathogen (Sharma et al. 2004, Wilcken et al. 2005, El-Moor et al. 2009).

The cultivar FB 200 Yellow Master is resistant to $M$. incognita race 2. Considering the presence of numerous areas infested with this nematode in Brazil, producers now have this cultivar as a farming option. 
Host status of progenies of yellow passion fruit to Meloidogyne incognita race 2

\section{REFERENCES}

Boneti JIS and Ferraz S (1981) Modificação do método de Hussey \& Barker para extração de ovos de Meloidogyne exigua em raízes de cafeeiro. Fitopatologia Brasileira 6: 553.

Castagnone-Sereno P, Danchin EG, Perfus-Barbeoch L and Abad P (2013) Diversity and evolution of root-knot nematodes, genus Meloidogyne: new insights from the genomic era. Annual Review of Phytopathology 51: 203-220.

Coolen WA and D'Herde CJ (1972) A method for the quantitative extraction of nematodes from plant tissue. State Agricultural Research Center, Ghent, 77p.

Dias-Arieira CR, Furlanetto C, Santana SM, Barizão DAO, Ribeiro RCF and Formentini HM (2010) Fitonematoides associados a frutíferas na região Noroeste do Paraná, Brasil. Revista Brasileira de Fruticultura 32: 1064-1071.

El-Moor RD, Peixoto JR, Ramos MLG and Mattos JKA (2006) Reação de dez progênies de maracujá-azedo (Passiflora edulis Sims f. flavicarpa Deneger) e do maracujá-doce (Passiflora alata Dryand) à raça 1 de Meloidogyne incognita. Bioscience Journal 22: 57-61.

El-Moor RD, Peixoto JR, Ramos MLG and Mattos JKA (2009) Reação de genótipos de maracujazeiro azedo aos nematóides de galhas (Meloidogyne incognita e Meloidogyne javanica). Bioscience Journal 25: 53-59.

Ferraz S, Freitas LG, Lopes EA and Dias-Arieira CR (2010) Manejo sustentável de fitonematoides. Editora UFV, Viçosa, 306p.

Fischer IH, Bueno CJ, Garcia MJM and Almeida AM (2010) Reação de maracujazeiro-amarelo ao complexo fusariose-nematoide de galha. Acta Scientiarum Agronomy 32: 223-227.

Fourie H, McDonald AH and De Waele D (2010) Relationships between initial population densities of Meloidogyne incognita race 2 and nematode population development in terms of variable soybean resistance. Journal of Nematology 42: 55-61.

Garcia MJDM, Almeida AM, Wilcken SRS, Fischer IH, Sampaio AL, Jesus AM and Fumis T (2008) Reação de maracujazeiro-amarelo 'Afruvec' e 'Maguary' a Meloidogyne spp. Arquivos do Instituto Biológico 75: 235-238.

Garcia MJDM, Fischer IH, Bueno CJ, Almeida AM, Sampaio AC, Wilcken SRS and Bertani RMA (2011) Reação de maracujazeiro amarelo a Meloidogyne incognita raça 3. Arquivos do Instituto Biológico 78: 137-139.

Hussey RS and Barker KR (1973) A comparison of methods of collecting inocula of Meloidogyne spp. including a new technique. Plant Disease Reporter 57: 1025-1028.
Jenkins WR (1964) A rapid centrifugal flotation technique for separating nematodes from soil. Plant Disease Reporter 48: 62.

Moens M, Perry RN and Starr JL (2009) Meloidogyne Species - a diverse group of novel and important plant parasites. In Perry RN, Moens M and Starr JL (eds) Root-knot nematodes. CABI, Wallingford, p. 1-17.

Oostenbrink M (1966) Major characteristics of the relation between nematodes and plants. Mededelingen Landbouwhogeschool Wageningen 66: 1-46.

Pegard A, Brizzard G, Fazari A, Soucaze O, Abad P and DjianCaporalino C (2005) Histological characterization of resistance to different root-knot nematode species related to phenolics accumulation in Capsicum annuum. Phytopathology 95: 158-165.

Proite K, Carneiro R, Falcão R, Gomes A, Leal-Bertioli S, Guimarães P and Bertioli D (2008) Post-infection development and histopathology of Meloidogyne arenaria race 1 on Arachis spp. Plant Pathology 57: 974-980.

Reis RV, Viana AP, Oliveira EJ and Silva MGM (2012) Phenotypic and molecular selection of yellow passion fruit progenies in the second cycle of recurrent selection. Crop Breeding and Applied Biotechnology 12: 17-24.

Rocha LS, Ribeiro RCF, Xavier AA, Silva FJ and Bruckner CH (2013) Reação de genótipos de maracujazeiro a Meloidogyne incognita raça 3 e Meloidogyne javanica. Revista Brasileira de Fruticultura 35: 10171024.

Santos LNS, Alves FR, Belan LL, Cabral PDS, Matta FP, Jesus Júnior WC and Moraes WB (2012) Damage quantification and reaction of bean genotypes (Phaseolus vulgaris L.) to Meloidogyne incognita race 3 and M. javanica. Summa Phytopathologica 38: 24-29.

Sharma RD, Junqueira NTV and Gomes AC (2001) Pathogenicity and reproduction of $M$. javanica on yellow passion fruit hibrids. Nematologia Brasileira 25: 247-249.

Sharma RD, Junqueira NTV and Gomes AC (2002) Reaction of passion fruit varieties to the root-knot nematode, Meloidogyne javanica. Nematologia Brasileira 26: 93-96.

Sharma RD, Junqueira NTV and Gomes AC (2004) Comportamento do maracujazeiro-doce (Passiflora alata) relacionado aos nematoide formadores de galhas. Nematologia Brasileira 28: 97-100.

Taylor AL and Sasser JN (1978) Biology, identification and control of rootknot nematodes (Meloidogyne sp.). North Carolina State University Graphics, Raleigh, 111p.

Wilcken SR, Garcia MJDM and Silva N (2005) Resistência de alface do tipo Americana a Meloidogyne incognita raça 2. Nematologia Brasileira 29: 267-271. 